\title{
REVIEW \\ Quinoa (Chenopodium quinoa Willd.) crop under Mediterranean conditions: a review
}

\author{
Dimitrios J. Bilalis, Ioannis Roussis, Ioanna Kakabouki, and Antigolena \\ Folina
}

Agricultural University of Athens, School of Agriculture, Engineering and Environmental Sciences, Department of Crop Science, Laboratory of Agronomy, 75 Iera Odos Str., 11855 Athens, Greece.

\begin{abstract}
D.J. Bilalis, I. Roussis, I. Kakabouki, and A. Folina. 2019. Quinoa (Chenopodium quinoa Willd.) crop under Mediterranean conditions: a review. Cien. Inv. Agr. 46(2): 51-68. Quinoa is a pseudocereal crop that is well adapted to a wide range of climatic conditions and has significant potential for increased production as a new crop in the Mediterranean region and in other parts of the world, including northern Europe, North America, Asia, and Africa. Because of its exceptional nutritional properties, quinoa is highly appreciated among humans as well as in animal nutrition for feeding both ruminants and nonruminating animals. Data obtained from several studies conducted in Greece, Italy, and Turkey demonstrate the high nutritional and functional potential of quinoa. Nitrogen fertilization has a positive effect on the growth and grain yield of quinoa crops. The biomass has high crude protein and low fiber and is competitive with alfalfa. The assessment of quinoa saponin content is of great importance for the industry. The highest saponin content and yield have been found under organic cropping systems. Oat, bean, and duckweed plants have a great phytotoxic response, especially to the inflorescence tissues of quinoa, confirming the potential allelopathic activity of this promising crop. The major part of the root system is concentrated in the upper 0-30 cm of the soil, and the root length density and root mass density increase with increasing applied nitrogen. In conclusion, quinoa may be suggested as a new alternative crop for semiarid and arid Mediterranean conditions affected by multiple abiotic stress factors because of its stresstolerant characteristics, adaptability to several agro-ecological conditions, and nutritional and economic value.
\end{abstract}

Keywords: Allelopathy, fodder crop, Mediterranean basin, root system, saponins.

\section{Introduction}

Climate is the primary determinant of agricultural productivity. Given the fundamental role of agriculture in human welfare, concern has been

Received Mar 11, 2019. Accepted Jun 04, 2019. Corresponding author: bilalisdimitrios@gmail.com expressed by several federal agencies regarding the potential effects of climate change on agricultural productivity during the last three decades (Adams et al., 1998). Climate change affects the conditions under which crops can be grown, particularly due to salinization and aridity (Schulze et al., 2005; Gregory, 2006; Jamil et al., 2011). In fact, soil and water salinity are wide- 
spread, with approximately one billion hectares estimated to be affected worldwide (Hasegawa, 2013). Moreover, salinity is increasing at a rate of $10 \%$ annually, and it has been estimated that more than $50 \%$ of arable land will be salinized by the year 2050 (Jamil et al., 2011). Climate change models also predict that future rainfall patterns will induce lower-frequency but stronger precipitation events, increasing the duration of dry soil conditions (Trenberth, 2011). As a result, crop productivity may be constrained by extended drought periods. At the same time, the human population is expected to increase from approximately 7.6 billion today to 9.8 billion in the year 2050 and 11.2 billion in 2100 (UN, 2017).

The Mediterranean region is characterized by an extremely variable climate with hot, dry summers and cold, wet winters (Ceccarelli et al., 2007). The Mediterranean climate is common to the western coasts of all continents between the latitudes of $30^{\circ}$ and $45^{\circ}$ because of global atmospheric circulation (Joffre and Rambal, 2001). The largest part of the Mediterranean climate area is the Mediterranean region, which constitutes $60 \%$ of the total area (Joffre and Rambal, 2001). Climate change will cause drier and hotter summers in addition to increased problems with soil salinity. By the year 2050, precipitation in winter months (OctoberMarch) will be increased in central and eastern Spain and north of Italy, while in the southern Mediterranean countries, precipitation will be decreased by $10-15 \%$. The average temperature in the Mediterranean region will be increased by $1.25-2.5^{\circ} \mathrm{C}$ in winter (Ragab and Prudhomme, 2002; Wang et al., 2003).

Crop production in the southern Mediterranean region is restricted by limited water resources, drought, and salinity. Under the semiarid and arid conditions in Mediterranean countries affected by multiple abiotic stress factors and further influenced by climate change, the typical crop cultivated is cereals in low-yielding monoculture or combined with fallow (Tekin et al., 2017). The adaptation of agriculture to changing climatic conditions includes the use of suitable crops, for example, species or genotypes within species with improved tolerance to abiotic stresses, such as cold, drought or saline soils (Scheben et al., 2016). The use of tolerant species or genotypes can also reduce the cost of remediation of saltcontaminated soil and clean-up of the polluted site. Although genetic variation within a species often results in the identification of tolerant genotypes, salt tolerance is generally low in most crops, except for a group of plants called halophytes, which can survive and reproduce in environments where the salt concentration exceeds $200 \mathrm{mM}$ of $\mathrm{NaCl}$ (Hasanuzzaman et al., 2014). Quinoa (Chenopodium quinoa Willd.) is a halophyte with the potential to become an important crop in arid regions and saline habitats and has expanded in many parts of the world to satisfy new market niches for gluten-free foods (Adolf et al., 2013). The abiotic stresses in the Mediterranean region are becoming even more pronounced due to the changing climate, which is predicted to bring drier conditions, increasing temperatures, and greater variability, causing desertification (Jacobsen, 2014).

Drought and salinity are the major problems associated with crop production in arid and semiarid regions, and substantial land areas are lost due to salinization each year (Munns and Tester, 2008). The use of salt-tolerant crops could be a suitable option to cope with salinity problems (Kökten et al., 2010). One such crop, and perhaps the most promising, is quinoa. Quinoa is well adapted to a wide range of marginal agricultural soils, including saline soils and those prone to drought. During the last two decades, numerous papers have addressed salt and drought tolerance in quinoa (Jensen et al., 2000; Garcia et al., 2003; Jacobsen and Mujica, 2003; Jacobsen et al., 2003; Bhargava et al., 2006; Garcia et al., 2007; Ruffino et al., 2010; Hariadi et al., 2011; Razzaghi et al., 2012; Adolf et al., 2013; Ruiz et al., 2014; Zurita-Silva et al., 2014; Choukr-Allah et al., 2016; Ruiz et al., 2016). Quinoa is a drought-tolerant crop that is capable of growing in extremely arid 
environments with less than $200 \mathrm{~mm}$ of annual precipitation (Fuentes and Bhargava, 2011). The wide genetic variability in salinity tolerance in quinoa provides an excellent source for selection and breeding for higher tolerance (Ruiz-Carrasco et al., 2011; Zurita-Silva et al., 2014). Quinoa can tolerate high levels of salinity, ranging from a salt concentration of 150 to $750 \mathrm{mM}$ of $\mathrm{NaCl}$ $\left(\sim 15-75 \mathrm{dS} \mathrm{m}^{-1}\right)$, which is greater than the salinity of seawater $\left(>45 \mathrm{dS} \mathrm{m}^{-1}\right)$ (Hinojosa et al., 2018). The optimal salinity conditions for quinoa growth range between 100 and $200 \mathrm{mM} \mathrm{NaCl}$ (Eisa et al., 2017). In general, quinoa combines a high natural tolerance to salinity (Pulvento et al., 2012) and a number of other environmental stress factors (Jacobsen et al., 2003; Razzaghi et al., 2011) with high nutritional quality (RepoCarrasco et al., 2003).

\section{General Information and Uses of Quinoa}

Quinoa (Chenopodium quinoa Willd.) belongs to the Amaranthaceae family and is a seed-producing crop that has been cultivated in the Andes for several thousand years (Tapia, 1982; Cusack, 1984). It is a dicotyledonous herbaceous plant species with wild relatives and domesticated populations. It is widely cultivated, from sea level at the coast to $4000 \mathrm{~m}$ above sea level. The plant's natural geographical distribution ranges from Colombia (Nariño, $1^{\circ} 39^{\prime} \mathrm{N}$ ) to Chile (southern part of the Andes, ca. $42^{\circ} \mathrm{S}$ ) and includes Bolivia, Peru, Ecuador, and Argentina (Fuentes et al., 2012). Quinoa is traditionally classified into five ecotypes (highland, inter-Andean valley, salares, Yungas, and coastal lowlands), which are associated with dispersion cores located in southern Peru and Bolivia close to Titicaca Lake (Tapia, 2015).

Currently, quinoa is emerging as an interesting crop for farmers and agro-industries, and it is considered a multipurpose crop (Galwey, 1992; Bhargava et al., 2006). The seed can be used for both human food and animal feedstock due to its exceptional nutritional value (Bhargava et al., 2006;
Nowak et al., 2016). As a consequence, the demand for quinoa seeds has significantly increased over the last decade (Bazile et al., 2016). However, its production in the traditional areas of cultivation is not sufficient to satisfy the increasing global demand, and thus it could be cultivated outside the equatorial Andes region of South America (Jacobsen, 2017).

The edible seeds are generally small, round, and flat. Seed size and color are variable, and black is dominant over red and yellow, which are successively dominant to white coloration (Risi and Galwey, 1984; Bhargava et al., 2006). Quinoa seeds are commonly known for their high nutritional value, mainly due to their high protein content and a wide range of minerals and vitamins (Fleming and Galwey, 1995). The high-quality proteins (14-20\%) are rich in essential amino acids, such as lysine, threonine, and methionine, that are deficient in cereals (Wright et al., 2002; Stikic et al., 2012). Quinoa is also high in linoleic and linolenic fatty acids and antioxidants, with 5-fold higher levels than cereal flours (Koziol, 1992). It contains considerable amounts of dietary fiber (7-10\%), vitamins (B, C, and E), and minerals ( $\mathrm{Ca}$, $\mathrm{Fe}, \mathrm{Zn}, \mathrm{Cu}$, and $\mathrm{Mn}$ ), as well as health-promoting compounds, such as polyphenols (Ruales and Nair, 1993; Repo-Carrasco et al., 2003; Ruiz et al., 2014). Many of the phenolic compounds identified in quinoa seeds, such as quercetin and kaempferol glycosides, can prevent degenerative diseases, such as coronary heart disease, atherosclerosis, diabetes and Alzheimer's disease (Hirose et al., 2010), and they are also potential chemopreventive and therapeutic agents against cancer (Matsubara et al., 2004).

In addition to its good nutritional composition, special attention has recently been given to quinoa as an alternative to cereals, such as wheat, rye, and barley, which contain gluten proteins (Bilalis et al., 2017). The seeds are used to make several gluten-free products, including bread, biscuits, cookies, crepes, muffins, and pancakes, for the increasing number of people with celiac disease 
or for customers who avoid gluten proteins for lifestyle reasons (Pulvento et al., 2010).

The starch content of quinoa varies from 52 to $60 \%$ and consists of small granules with a diameter ranging from 0.2 to $3.2 \mu \mathrm{m}$ (Koziol, 1992; Li and Zhu, 2018). Quinoa starch is suitable for emulsion food products (Ahamed et al., 1996). It has the potential to be used for specialized industrial applications due to its small granules and high viscosity. Specifically, it can be used as a dusting starch in cosmetics and as a rubber mold release agent (Galwey et al., 1990).

The nutritional value of quinoa seed has long been considered superior to that of cereals and milk solids in animal feed rations (White et al., 1955). Quinoa seed, administered whole or ground, can be used as an alternative to cereal grains for feeding monogastric animals, especially poultry and pigs (Blanco, 2015). According to a study by Jacobsen et al. (1997), the incorporation of 150 $\mathrm{g} \mathrm{kg}^{-1}$ unprocessed or dehusked quinoa seed into poultry feeds can greatly benefit poultry production.

In addition to its nutrient content, quinoa contains bitter and toxic compounds, especially in the seed hull. Saponins are the principle antinutritional factors present in the seed coat of quinoa. These antinutritional compounds have a bitter taste that significantly limits the use of quinoa as food or feed. Therefore, for most uses, quinoa is dehusked and washed before consumption (Lopez-Garcia, 2007). It is known that the levels of saponins in quinoa seeds depend on the genotype. Specifically, the saponin content in seeds of sweet genotypes varies from 0.2 to $0.4 \mathrm{~g} \mathrm{~kg}^{-1}$ dry matter, while in bitter genotypes, it varies from 4.7 to $11.3 \mathrm{~g} \mathrm{~kg}^{-1}$ dry matter (Mastebroek et al., 2000). However, saponins are considered to be bioactive compounds with analgesic, antiallergic and antioxidant properties (Güçlü-Üstündag and Mazza, 2007; Kuljanabhagavad et al., 2008). Moreover, their insecticidal, fungicidal, antibiotic and pharmacological properties contribute to the plant's defense against pests and pathogens (Vega-Gálvez et al., 2010; Carlson et al., 2012). The presence of saponins in quinoa also offers an additional use for this species as an alternative source of these compounds for industrial applications in soaps, detergents, shampoos, beer, photography and cosmetics (Güçlü-Üstündag and Mazza, 2007) and as supplements for chemotherapy (Tian et al., 2013).

The use of the whole quinoa plant as a source of feed for animals is becoming popular because of its high nutritional value. If quinoa is cultivated as a green fodder crop and harvested near the flowering stage, the biomass has high crude protein and low fiber, and the plant is competitive with alfalfa (Medicago sativa L.) when compared on a cost basis (Peterson and Murphy, 2015). The foliage of quinoa contains an abundant amount of ash (3.3\%), fiber (1.9\%), nitrates $(0.4 \%)$, vitamin $\mathrm{E}$ (2.9 mg $\alpha$-TE $\left.100 \mathrm{~g} \mathrm{~g}^{-1}\right), \mathrm{Na}\left(289 \mathrm{mg} 100 \mathrm{~g}^{-1}\right)$, vita$\min \mathrm{C}\left(1.2-2.3 \mathrm{~g} \mathrm{~kg}^{-1}\right)$ and protein $\left(27-30 \mathrm{~g} \mathrm{~kg}^{-1}\right)$ (Bhargava et al., 2006) and can be fed to sheep, goats, bovines and fish (Francis et al., 2002) or can be used for silage (Peterson and Murphy, 2015).

In view of its extraordinary nutritional properties and ability to grow in a wide range of marginal environments, the Food and Agriculture Organization of the United Nations (FAO) has identified quinoa as an important alternative to contribute to future global food security and declared the year 2013 as the international year of quinoa (FAO, 2012). Currently, the demand for quinoa is growing worldwide, especially in the health food segment, but current supplies are unable to match it. In addition to its use for human consumption, quinoa seed has other uses as livestock and poultry feed. The whole plant can be used as green fodder, and the harvest residues can also be fed to animals.

\section{The Global Expansion of Quinoa}

From 7000 years ago until the late 1970s, quinoa was only cultivated in the Andes. The wide di- 
versity of quinoa uses, its high levels of genetic diversity, its exceptional nutritional quality, and its potential to grow in a wide range of marginal environments away from the traditional areas of cultivation in the Andes have made this crop very popular in Europe and worldwide, such as in the USA, Canada, Australia, Africa, and Southeast Asia (Ruiz et al., 2014; Bazile et al., 2016; Jacobsen, 2017). The number of countries growing quinoa has increased rapidly from 8 in 1980 to 75 in 2014, with another 20 countries having sown quinoa for the first time in 2015 (Bazile and Baudron, 2015). The FAO project "American and European Test of Quinoa" (1996-1998) was the first mechanism for the distribution of quinoa worldwide, and it underlies the current global expansion of the crop (Mujica et al., 2001). Apart from the successful introduction and cultivation of quinoa in regions of northern Europe since the late 1970s and early 1980s (England, Denmark, and the Netherlands) (Tapia, 1979; Jacobsen and Stolen, 1993; Mastebroek and Limburg, 1996; Jacobsen, 2003), the crop has also been successfully trialed in Mediterranean basin countries (in Greece since the mid-1990s and in Italy and Turkey since the late 2000s) (Iliadis et al., 1997; Taviani et al., 2008; Bilalis et al., 2012; Yazar, 2015).

This research article attempts to provide the main results of the research studies carried out on quinoa growth performance in the Mediterranean region (Greece, Italy, and Turkey).

\section{Quinoa Experimentation in the Mediterranean Region}

\section{Experiments and Results in Greece}

Quinoa was introduced to Greece for the first time in 1995, as Greece is one of the European countries (Sweden, Poland, the Czech Republic, Austria, and Finland) involved in the international research program entitled "American and European Test of Quinoa" (AETQ) organized by the Food and Agriculture Organization of the United Nations
(FAO) and the quinoa project "CIP-DANIDA". This initiative was undertaken by the International Potato Center in Lima (Peru), and its main purposes were to improve quinoa cultivation, to introduce new uses of the crop and to enhance market demands (Iliadis et al., 1997; Sanchez et al., 1998; Iliades et al., 1999; Iliadis et al., 2001).

Within the framework of this project, the first experiments addressing the adaptation of quinoa in the Mediterranean basin were conducted in Larissa, central Greece $\left(22^{\circ} 25^{\prime} \mathrm{N}, 39^{\circ} 36^{\prime} \mathrm{E}, 73 \mathrm{~m}\right.$ above sea level) from 1995 until 2004 (Noulas et al., 2017). The experimental trials were conducted at the research stations of the Fodder Crops and Pastures Institute in cooperation with the Institute for Soil Mapping and Classification of Larissa (Hellenic Agricultural Organization "Demeter"; ELGO “DEMETER”; Hellenic Ministry of Rural Development and Food).

The results derived from these field experiments indicated several notable observations and conclusions regarding the growth performance of quinoa crops under varying climate conditions in the Mediterranean region. First, it was found that a wide range of soils is acceptable for quinoa cultivation; however, crusting and desiccation of the topsoil can reduce the germination potential. In addition, quinoa may be cultivated in heavy soils, but only with the appropriate use of fertilization and irrigation regimes (Iliadis et al., 2001). Early sowing (March) is suitable for cultivation of quinoa, providing that frost avoidance is ensured, while late sowing (May) results in low germinability. The optimum sowing density is 25 plants $\mathrm{m}^{-2}$ or $10 \mathrm{~kg} \mathrm{ha}^{-1}$ (Iliades et al., 1999). The seed yield under the climatic conditions in central Greece exceeds 1000-1500 kg ha ${ }^{-1}$, and the biomass yield of the dry stems varies between 6000 and $9000 \mathrm{~kg} \mathrm{ha}^{-1}$ (Iliades et al., 1999; Iliadis et al., 2001). In addition, the seed yield in marginal (saline-sodic) soil conditions is decreased by $45 \%$ (Karyotis et al., 2003). Quinoa seeds are rich in protein (14.89-19.03\%) and minerals $(\mathrm{P}=2.97-3.92$ $\mathrm{g} \mathrm{kg}^{-1} ; \mathrm{Ca}=2.48-5.48 \mathrm{~g} \mathrm{~kg}^{-1} ; \mathrm{K}=14.42-22.63 \mathrm{~g} \mathrm{~kg}^{-1}$; $\mathrm{Na}=0.36-2.13 \mathrm{~g} \mathrm{~kg}^{-1}$ ) under various soil conditions 
(Vertisol with neutral conditions and Inceptisol with saline-sodic conditions), and for this reason, quinoa can adapt to marginal environments and produce high-quality seeds (Karyotis et al., 2003). The dry stems of plants left after the seed harvest contain a high percentage of fiber content ranging between 38.8 and $50.8 \%$ (Iliades et al., 2001). Quinoa is also tolerant to the drought conditions that prevail in Greece; however, irrigation during the $4^{\text {th }}$ to $6^{\text {th }}$ leaf stage is required (Iliades et al., 1999). Finally, the growing cycle of quinoa in Greece is 100-116 days, while the growing cycle in northern Europe is 110-180 days (Jacobsen, 2003).

Organic field trials conducted by the Agricultural University of Athens over two years (2010-2011) in western Greece were carried out to investigate two tillage systems (conventional and minimum tillage) combined with three organic fertilization regimes [control (untreated), cow manure $(2000 \mathrm{~kg}$ $\mathrm{ha}^{-1}$ with $\left.1.24 \% \mathrm{~N}\right)$ and seaweed compost $(250 \mathrm{~kg}$ ha $^{-1}$ with $\left.8 \% \mathrm{~N}\right)$ ] and their effects on soil properties and yield and quality parameters of the quinoa crop (Bilalis et al., 2012). Minimum tillage had a more positive impact than conventional tillage and significantly affected soil porosity (45.5-49.75\%), total nitrogen $(0.144-0.173 \%)$ and root density $\left(1.03-1.21 \mathrm{~cm} \mathrm{~cm}^{-3}\right)$, resulting in a higher leaf area index (4.47-5.03) and aboveground biomass $\left(8650-9290 \mathrm{~kg} \mathrm{ha}^{-1}\right)$. Quinoa saponin content is very important in the industry. No significant differences were observed in saponin content between the different tillage systems. The highest values of seed yield (2485-2643 $\left.\mathrm{kg} \mathrm{ha}^{-1}\right)$ and saponin content $(0.42-0.45 \%)$ were observed in manure and compost plots. The highest saponin yield $\left(7.70-12.05 \mathrm{~kg} \mathrm{ha}^{-1}\right)$ was observed in soils subjected to the minimum tillage system (Table 1, adapted from Bilalis et al., 2012). The results indicate that minimum soil tillage combined with organic fertilization increases the saponin content and yield of quinoa.

Table 1. Effects of tillage system (conventional and minimum tillage: CT and MT, respectively) and organic fertilization [control, cow manure and compost] on seed yield $\left(\mathrm{kg} \mathrm{ha}^{-1}\right)$, saponin content $(\%)$ and saponin yield $\left(\mathrm{kg} \mathrm{ha}^{-1}\right)$ of quinoa crop (adapted from Bilalis et al., 2012).

\begin{tabular}{|c|c|c|c|c|c|c|}
\hline \multirow{2}{*}{ Fertilization } & \multicolumn{6}{|c|}{ Tillage System } \\
\hline & $\mathrm{CT}$ & MT & $\mathrm{CT}$ & MT & $\mathrm{CT}$ & MT \\
\hline 2010 & \multicolumn{2}{|c|}{$\begin{array}{l}\text { Seed Yield } \\
\left(\mathrm{kg} \mathrm{ha}^{-1}\right)\end{array}$} & \multicolumn{2}{|c|}{ Saponin Content (\%) } & \multicolumn{2}{|c|}{$\begin{array}{l}\text { Saponin Yield } \\
\quad\left(\mathrm{kg} \mathrm{ha}^{-1}\right)\end{array}$} \\
\hline Control & 2175 & 2325 & 0.30 & 0.33 & 6.58 & 7.70 \\
\hline Cow Manure & 2450 & 2578 & 0.41 & 0.44 & 10.11 & 11.40 \\
\hline Compost & 2374 & 2485 & 0.39 & 0.42 & 9.34 & 10.52 \\
\hline $\mathrm{F}_{\text {tillage }}$ & \multicolumn{2}{|c|}{$\begin{array}{c}17.83^{*} \\
(\mathrm{LSD}=97.26)\end{array}$} & \multicolumn{2}{|c|}{$5.44 \mathrm{~ns}$} & \multicolumn{2}{|c|}{$\begin{array}{c}16.71^{*} \\
(\mathrm{LSD}=0.92)\end{array}$} \\
\hline $\mathrm{F}_{\text {fertilization }}$ & \multicolumn{2}{|c|}{$\begin{array}{c}39.52 * * * \\
(\mathrm{LSD}=50.69)\end{array}$} & \multicolumn{2}{|c|}{$\begin{array}{c}63.87 * * * \\
(\mathrm{LSD}=0.024)\end{array}$} & \multicolumn{2}{|c|}{$\begin{array}{c}53.56 * * * \\
(\mathrm{LSD}=0.86)\end{array}$} \\
\hline$F_{\text {tillage } X \text { fertilization }}$ & \multicolumn{2}{|c|}{$0.48 \mathrm{~ns}$} & \multicolumn{2}{|c|}{$1.74 \mathrm{~ns}$} & \multicolumn{2}{|c|}{$0.85 \mathrm{~ns}$} \\
\hline 2011 & \multicolumn{2}{|c|}{$\begin{array}{l}\text { Seed Yield } \\
\left(\mathrm{kg} \mathrm{ha}^{-1}\right)\end{array}$} & \multicolumn{2}{|c|}{ Saponin Content (\%) } & \multicolumn{2}{|c|}{$\begin{array}{l}\text { Saponin Yield } \\
\left(\mathrm{kg} \mathrm{ha}^{-1}\right)\end{array}$} \\
\hline Control & 2315 & 2415 & 0.32 & 0.35 & 7.34 & 8.43 \\
\hline Cow Manure & 2525 & 2643 & 0.44 & 0.45 & 11.03 & 12.05 \\
\hline Compost & 2413 & 2538 & 0.41 & 0.45 & 9.90 & 11.35 \\
\hline $\mathrm{F}_{\text {tillage }}$ & \multicolumn{2}{|c|}{$\begin{array}{c}12.11 * \\
(\mathrm{LSD}=104.42)\end{array}$} & \multicolumn{2}{|c|}{$6.15 \mathrm{~ns}$} & \multicolumn{2}{|c|}{$14.03 \mathrm{~ns}$} \\
\hline $\mathrm{F}_{\text {fertilization }}$ & \multicolumn{2}{|c|}{$\begin{array}{c}35.67 * * * \\
(\mathrm{LSD}=56.43)\end{array}$} & \multicolumn{2}{|c|}{$\begin{array}{c}70.75 * * * \\
(\mathrm{LSD}=0.022)\end{array}$} & \multicolumn{2}{|c|}{$\begin{array}{c}63.40 * * * \\
(\mathrm{LSD}=0.73)\end{array}$} \\
\hline$F_{\text {tillage } X \text { fertilization }}$ & \multicolumn{2}{|c|}{$0.12 \mathrm{~ns}$} & \multicolumn{2}{|c|}{$0.43 \mathrm{~ns}$} & \multicolumn{2}{|c|}{$0.23 \mathrm{~ns}$} \\
\hline
\end{tabular}

F-test ratios are from ANOVA. Significant at *,** and $* * *$ indicate significance at $\mathrm{p}=0.05,0.01$ and 0.001 , respectively, and ns: not significant. The least significant difference $(\mathrm{LSD})$ test $(\mathrm{p}=0.05)$ values for tillage system and organic fertilization are also presented. 
In the Agrinio area (western Greece, $38^{\circ} 35^{\prime} \mathrm{N}$, $21^{\circ} 25^{\prime} \mathrm{E}$ ) from 2011 to 2013 , field trials were performed to investigate the influence of tillage system [conventional tillage (moldboard plowing at $25 \mathrm{~cm}$ followed by one rotary hoeing at $10-15 \mathrm{~cm}$ ) and minimum tillage (chiseling at 25 $\mathrm{cm}$ depth followed by chiseling at $10-15 \mathrm{~cm}$ )] and fertilizer application [control (untreated), sheep manure ( $3000 \mathrm{~kg} \mathrm{ha}^{-1}$ with $\left.11.52 \% \mathrm{~N}\right)$, and inorganic fertilization (26-0-0) with $100 \mathrm{~kg} \mathrm{~N}$ $\mathrm{ha}^{-1}$ (N1) and $200 \mathrm{~kg} \mathrm{~N} \mathrm{ha}^{-1}$ (N2) fertilizer] on soil properties and the performance of a quinoa (Chenopodium quinoa Willd. cv. 'Faro') crop (Kakabouki, 2016). Regarding the studied soil properties, the mean weight diameter of soil aggregates, total porosity, organic matter and soil total nitrogen increased with long-term fertilization in manure plots. The root length density of quinoa increased with increasing applied nitrogen rates, and the highest value $\left(1.172 \mathrm{~cm} \mathrm{~cm}^{-3}\right)$ was found in N2 plots. On the other hand, root mass density was affected by the tillage system, and the highest value ( $1.114 \mathrm{mg} \mathrm{cm}^{-3}$ ) was observed under minimum tillage. The highest seed yield (2595 $\mathrm{kg} \mathrm{ha}^{-1}$ ) was found in the conventional system combined with the $\mathrm{N} 2$ treatment. Concerning the aboveground biomass of the crop, the dry weight was influenced by both fertilization and soil tillage (Kakabouki et al., 2014). The lowest weight $\left(8020 \mathrm{~kg} \mathrm{ha}^{-1}\right)$ was found in the minimum tillage system combined with the control treatment (no fertilization). With reference to biomass quality, the highest crude protein yield $\left(2481 \mathrm{~kg} \mathrm{ha}^{-1}\right.$ and $2356 \mathrm{~kg} \mathrm{ha}^{-1}$ for conventional and minimum tillage, respectively) and acid detergent fiber (ADF: $35.80 \%$ and $39.45 \%$ for CT and MT, respectively) were found in the $\mathrm{N} 2$ treatment, while the total ash content (13.08-14.71\%) was not influenced by the tillage systems or fertilization regimes (Table 2, adapted from Kakabouki et al., 2014).

During the experiments in the Agrinio area, the nitrogen uptake and utilization efficiency of quinoa were also evaluated, and the results showed that these traits were only affected by fertilization (Kakabouki et al., 2018). The highest biomass nitrogen content (4.08-4.33\%), biomass nitrogen yield (371-386 $\mathrm{kg} \mathrm{N} \mathrm{ha}^{-1}$ ), seed nitrogen content (2.59-2.78\%), seed nitrogen yield (62.58-65.42 $\left.\mathrm{kg} \mathrm{N} \mathrm{ha}^{-1}\right)$, and total plant nitrogen uptake (437.20-454.93 $\mathrm{kg} \mathrm{N} \mathrm{ha}^{-1}$ ) were obtained in the N2 plots. The nitrogen harvest index (NHI) and nitrogen utilization efficiency (NUtE) were up to $60 \%$ lower and $40 \%$ lower, respectively, in the inorganic treatments than in the untreated (control) plots. Rates of nitrogen higher than $100 \mathrm{~kg} \mathrm{~N} \mathrm{ha}^{-1}(\mathrm{~N} 1)$ did not increase the nitrogen agronomic efficiency (NAE) (Table 3, adapted

Table 2. Effects of tillage system (conventional and minimum tillage: CT and MT, respectively) and fertilization [control, inorganic fertilization at $100 \mathrm{~kg} \mathrm{~N}^{-1}(\mathrm{~N} 1)$, inorganic fertilization at $200 \mathrm{~kg} \mathrm{~N} \mathrm{ha}^{-1}(\mathrm{~N} 2)$ and sheep manure] on biomass dry weight $\left(\mathrm{kg} \mathrm{ha}^{-1}\right)$, leaf area index (LAI), total ash (\%) and acid detergent fiber (ADF; \%) of quinoa crop (adapted from Kakabouki et al., 2014).

\begin{tabular}{|c|c|c|c|c|c|c|c|c|}
\hline \multirow{2}{*}{ Fertilization } & \multicolumn{8}{|c|}{ Tillage System } \\
\hline & $\mathrm{CT}$ & MT & $\mathrm{CT}$ & MT & $\mathrm{CT}$ & MT & $\mathrm{CT}$ & MT \\
\hline 2012 & \multicolumn{2}{|c|}{ Biomass Dry Weight $\left(\mathrm{kg} \mathrm{ha}^{-1}\right)$} & \multicolumn{2}{|c|}{ Leaf Area Index (LAI) } & \multicolumn{2}{|c|}{ Total Ash (\%) } & \multicolumn{2}{|c|}{ Acid Detergent Fiber (ADF) (\%) } \\
\hline Control & 8205 & 8020 & 4.30 & 4.45 & 14.11 & 14.41 & 29.72 & 27.78 \\
\hline N1 & 8725 & 8390 & 4.75 & 4.35 & 13.88 & 14.71 & 30.23 & 36.80 \\
\hline $\mathrm{N} 2$ & 9165 & 8705 & 4.25 & 4.45 & 14.65 & 14.65 & 35.80 & 39.45 \\
\hline Manure & 9170 & 9010 & 4.70 & 4.65 & 13.08 & 13.86 & 24.78 & 27.95 \\
\hline $\mathrm{F}_{\text {tillage }}$ & \multicolumn{2}{|c|}{$\begin{array}{c}5.26^{*} \\
(\mathrm{LSD}=143)\end{array}$} & \multicolumn{2}{|c|}{$0.03 \mathrm{~ns}$} & \multicolumn{2}{|c|}{$1.23 \mathrm{~ns}$} & \multicolumn{2}{|c|}{ W4.96ns } \\
\hline $\mathrm{F}_{\text {fertilization }}$ & \multicolumn{2}{|c|}{$\begin{array}{c}31.42 * * * \\
(\mathrm{LSD}=229)\end{array}$} & \multicolumn{2}{|c|}{$1.32 \mathrm{~ns}$} & \multicolumn{2}{|c|}{$1.34 \mathrm{~ns}$} & \multicolumn{2}{|c|}{$\begin{array}{c}15.25 * * * \\
(\mathrm{LSD}=4.19)\end{array}$} \\
\hline
\end{tabular}

F-test ratios are from ANOVA. Significant at * $* *$ and $* * *$ indicate significance at $\mathrm{p}=0.05,0.01$ and 0.001 , respectively, and ns: not significant. The least significant difference (LSD) test $(\mathrm{p}=0.05)$ values for tillage system and fertilization are also presented. 
from Kakabouki et al., 2018). The highest rates of the change in nitrate reduction in the soil (-0.108 to $-0.188 \mathrm{~N} \%$ day $\left.^{-1}\right)$ and nitrogen increase in the plant $\left(0.025\right.$ to $0.027 \mathrm{~N} \%$ day $\left.^{-1}\right)$ were observed under the application of the highest quantity of inorganic nitrogen fertilizer.

In terms of the weed flora associated with quinoa crops, seed yield in conventional tillage systems was found to be $5-13 \%$ higher than that under minimum tillage, likely due to the lower weed density and biomass (Kakabouki et al., 2015). In addition, the density of perennial weeds, such as purple nutsedge (Cyperus rotundus L.), and the density of small-seeded weeds, such as redroot pigweed (Amaranthus retroflexus L.) and common purslane (Portulaca oleracea L.), were significantly lower under conventional tillage than under the minimum tillage system.

Finally, the results of this study can be summarized as follows: a) increasing levels of applied nitrogen up to $200 \mathrm{~kg} \mathrm{~N} \mathrm{ha}^{-1}$ can improve the growth of the root system and consequently the seed yield, b) the whole quinoa plant can be fed to ruminants as an alternative to legumes, c) quinoa has a high capacity to take up nitrate from the soil and can be used as a phytoremediation plant; however, it presents low nitrogen remobilization from the vegetative parts to the seeds under a high nitrogen supply, and d) the adoption of minimum tillage systems can increase weed density and reduce the seed yield of quinoa.

The allelopathic effects of three plant tissues (leaves, roots, and inflorescences) of quinoa on the aboveground (seedlings) and underground (roots) growth of oats in pot experiments was investigated by Bilalis et al. (2013). The different tissues of the quinoa plants exhibited different allelopathic activities. Oat growth (fresh and dry weight of above- and underground parts) was significantly inhibited by the phytotoxic activity of the inflorescence, leaf, and root tissues of quinoa. The quantification of the phytotoxicity of quinoa plant extracts by means of three bioassay methods (seed germination and radicle growth of oats, fresh and dry weight of common beans, and fresh weight of duckweed plants) revealed that the three tested species presented a greater phytotoxic response when exposed to the inflorescences than the other tissue parts (leaves and stems, roots) of quinoa (Bilalis et al., 2013).

In the experimental field of the Agricultural University of Athens (Attica region, centralsouthern Greece, $37^{\circ} 59^{\prime} \mathrm{N}, 23^{\circ} 42^{\prime} \mathrm{E}, 29 \mathrm{~m}$ above sea level), during the cultivation period of March to July 2013, a field trial was conducted to study the response of quinoa and green amaranth to different fertilization regimes [(control, inorganic fertilization (26-0-0) with $100 \mathrm{~kg} \mathrm{~N} \mathrm{ha}^{-1}$ fertilizer, seaweed compost (2000 kg ha-1 with $1-2 \%$ compost) and cow manure (2000 $\mathrm{kg} \mathrm{ha}^{-1}$ with $1.24 \%$ N)] (Papastylianou et al., 2014). The results indicated that fertilization with compost resulted in a higher yield ( $\left.8430 \mathrm{~kg} \mathrm{ha}^{-1}\right)$ and better-quality traits (18.8\% total ash, $2.87 \%$ crude fat and $14.7 \%$ crude protein) of quinoa biomass. In conclusion, Papastylianou et al. (2014) suggested that quinoa could be used as an alternative feed crop to substitute spring legume species in Mediterranean semiarid areas.

\section{Experiments and Results in Italy}

In 2006, field trials began at the ISAFoM CNR (Institute for Agricultural and Forest Systems in the Mediterranean of the Italian National Research Council) research station located in Vitulazio on the Volturno river plain $\left(14^{\circ} 50^{\prime} \mathrm{E}, 40^{\circ} 70^{\prime} \mathrm{N} ; 25\right.$ $\mathrm{m}$ above sea level), an irrigated area in southern Italy (Lavini et al., 2014).

During the first two experimental years, quinoa was studied within the project "CO.Al.Ta. II" (Alternative Crops to Tobacco) founded by the European Community (EC). The aim of the first experiment was to evaluate the effects of different sowing dates (5 April and 4 May) on the yield and the main chemical and nutritional 
Table 3. Effects of tillage system (conventional and minimum tillage: CT and MT, respectively) and fertilization [control, inorganic fertilization at $100 \mathrm{~kg} \mathrm{~N} \mathrm{ha}^{-1}(\mathrm{~N} 1)$, inorganic fertilization at $200 \mathrm{~kg} \mathrm{~N} \mathrm{ha}^{-1}(\mathrm{~N} 2)$ and sheep manure] on the nitrogen harvest index (NHI), nitrogen utilization efficiency (NUtE) and nitrogen agronomic efficiency (NAE) of quinoa crop (adapted from Kakabouki et al., 2018).

\begin{tabular}{|c|c|c|c|c|c|c|}
\hline \multirow{2}{*}{ Fertilization } & \multicolumn{6}{|c|}{ Tillage System } \\
\hline & $\mathrm{CT}$ & MT & $\mathrm{CT}$ & MT & $\mathrm{CT}$ & MT \\
\hline 2011 & \multicolumn{2}{|c|}{ Nitrogen Harvest Index (NHI) } & \multicolumn{2}{|c|}{$\begin{array}{l}\text { Nitrogen Utilization Efficiency } \\
\text { (NUtE) }\end{array}$} & \multicolumn{2}{|c|}{$\begin{array}{c}\text { Nitrogen Agronomic } \\
\text { Efficiency (NAE) }\end{array}$} \\
\hline Control & 0.19 & 0.17 & 11.70 & 9.96 & - & - \\
\hline N1 & 0.17 & 0.15 & 8.78 & 7.83 & 0.95 & 1.00 \\
\hline $\mathrm{N} 2$ & 0.15 & 0.14 & 6.73 & 6.11 & 0.55 & 0.45 \\
\hline Manure & 0.21 & 0.18 & 11.31 & 10.21 & 0.71 & 0.51 \\
\hline $\mathrm{F}_{\text {tillage }}$ & \multicolumn{2}{|c|}{$\begin{array}{c}5.83^{*} \\
(\text { Tukey's test }=0.027)\end{array}$} & \multicolumn{2}{|c|}{$3.62 \mathrm{~ns}$} & \multicolumn{2}{|c|}{$0.11 \mathrm{~ns}$} \\
\hline $\mathrm{F}_{\text {fertilization }}$ & \multicolumn{2}{|c|}{$\begin{array}{c}8.89 * * \\
(\text { Tukey's test }=0.036)\end{array}$} & \multicolumn{2}{|c|}{$\begin{array}{c}13.43^{* *} \\
(\text { Tukey's test }=2.446)\end{array}$} & \multicolumn{2}{|c|}{$1.32 \mathrm{~ns}$} \\
\hline$F_{\text {tillage X fertilization }}$ & \multicolumn{2}{|c|}{$0.11 \mathrm{~ns}$} & \multicolumn{2}{|c|}{$0.16 \mathrm{~ns}$} & \multicolumn{2}{|c|}{$0.08 \mathrm{~ns}$} \\
\hline 2012 & \multicolumn{2}{|c|}{ Nitrogen Harvest Index (NHI) } & \multicolumn{2}{|c|}{$\begin{array}{l}\text { Nitrogen Utilization Efficiency } \\
\text { (NUtE) }\end{array}$} & \multicolumn{2}{|c|}{$\begin{array}{l}\text { Nitrogen Agronomic } \\
\text { Efficiency (NAE) }\end{array}$} \\
\hline Control & 0.19 & 0.18 & 11.69 & 10.48 & - & - \\
\hline N1 & 0.15 & 0.17 & 7.69 & 8.01 & 1.10 & 2.27 \\
\hline $\mathrm{N} 2$ & 0.15 & 0.15 & 6.53 & 6.09 & 1.20 & 1.08 \\
\hline Manure & 0.16 & 0.16 & 8.51 & 7.99 & 0.78 & 1.20 \\
\hline $\mathrm{F}_{\text {tillage }}$ & \multicolumn{2}{|c|}{$0.01 \mathrm{~ns}$} & \multicolumn{2}{|c|}{$2.44 \mathrm{~ns}$} & \multicolumn{2}{|c|}{$1.42 \mathrm{~ns}$} \\
\hline $\mathrm{F}_{\text {fertilization }}$ & \multicolumn{2}{|c|}{$\begin{array}{c}5.01^{*} \\
(\text { Tukey's test }=0.027)\end{array}$} & \multicolumn{2}{|c|}{$\begin{array}{c}45.37 * * * \\
(\text { Tukey's test }=1.331)\end{array}$} & \multicolumn{2}{|c|}{$1.06 \mathrm{~ns}$} \\
\hline $\mathrm{F}_{\text {tillage } \mathrm{X} \text { fertilization }}$ & \multicolumn{2}{|c|}{$0.53 \mathrm{~ns}$} & \multicolumn{2}{|c|}{$1.12 \mathrm{~ns}$} & \multicolumn{2}{|c|}{$0.84 \mathrm{~ns}$} \\
\hline 2013 & \multicolumn{2}{|c|}{ Nitrogen Harvest Index (NHI) } & \multicolumn{2}{|c|}{$\begin{array}{l}\text { Nitrogen Utilization Efficiency } \\
\text { (NUtE) }\end{array}$} & \multicolumn{2}{|c|}{$\begin{array}{l}\text { Nitrogen Agronomic } \\
\text { Efficiency (NAE) }\end{array}$} \\
\hline Control & 0.18 & 0.17 & 10.76 & 10.01 & - & - \\
\hline N1 & 0.16 & 0.16 & 7.70 & 7.80 & 2.25 & 3.60 \\
\hline $\mathrm{N} 2$ & 0.15 & 0.15 & 6.50 & 6.32 & 2.10 & 2.40 \\
\hline Manure & 0.17 & 0.16 & 7.76 & 7.68 & 0.31 & 0.82 \\
\hline $\mathrm{F}_{\text {tillage }}$ & \multicolumn{2}{|c|}{$0.23 \mathrm{~ns}$} & \multicolumn{2}{|c|}{$0.08 \mathrm{~ns}$} & \multicolumn{2}{|c|}{$2.14 \mathrm{~ns}$} \\
\hline $\mathrm{F}_{\text {fertilization }}$ & \multicolumn{2}{|c|}{$0.58 \mathrm{~ns}$} & & $t=2.737)$ & (Tul & $=1.685)$ \\
\hline$F_{\text {tillage } X \text { fertilization }}$ & & & & & & \\
\hline
\end{tabular}

F-test ratios are from ANOVA. Significant at *,** and *** indicate significance at $\mathrm{p}=0.05,0.01$ and 0.001 , respectively, and ns: not significant. Tukey's test $(\mathrm{p}=0.05)$ values for tillage system and fertilization are also presented.

properties of the seeds of two quinoa genotypes [Titicaca (KVLQ520Y) and Regalona Baer (RB)] under rainfed conditions (Pulvento et al., 2010). The results showed that April was the best time for sowing quinoa in the Mediterranean region because it resulted in higher yields $\left(3.28 \mathrm{t} \mathrm{ha}^{-1}\right)$ than sowing in May $\left(1.50 \mathrm{t} \mathrm{ha}^{-1}\right)$. In regard to the genotypes, cv. 'Regalona Baer' showed better growth and productivity (achene yield: 3.42 and $3.00 \mathrm{t} \mathrm{ha}^{-1}$ in 2006 and 2007, respectively), apparently being more tolerant to abiotic stress, specifically at high temperatures under water stress. The protein content of the different quinoa samples varied between 16.2 and $16.8 \%$. The saponin content of the seeds was significantly higher in cv. 'Regalona Baer' (329.0 mg per 100 g dry weight) than in cv. 'Titicaca' (213.8-238.9 mg per 100 g dry weight).

Cultivar 'Titicaca' was studied again in a biannual field trial (2009-2010) conducted at the ISAFoM CNR research station. The purpose of this study was to investigate the effects of salt and drought stress on the growth, yield, quality and ecophysi- 
ological parameters of the crop (Gómez-Caravaca et al., 2012; Pulvento et al., 2012; Cocozza et al., 2013; Ricardi et al., 2014). Three treatments involving irrigation with well water (Q100, Q50 and Q25) and corresponding treatments involving irrigation with saline water (Q100S, Q50S and Q25S) with an electrical conductivity (ECw) of $22 \mathrm{dS} \mathrm{m}^{-1}$ were implemented. Q100 represented the control, receiving $100 \%$ of the water necessary to replenish the soil to field capacity in the root zone of the soil $(0.00-0.36 \mathrm{~m})$. For Q50 and Q25, 50\% and 25\% of the water volume used for the control treatment were applied, respectively. Salt and drought stress in both years of the experiment did not cause a significant yield reduction, with the average seed yield being 2.3-2.7 $\mathrm{t} \mathrm{ha}^{-1}$. However, the application of the highest level of saline water resulted in the highest mean seed weight and, as a consequence, an increase in fiber (19.4-21.6 g per $100 \mathrm{~g}$ dry weight) and total saponin content (1180.3-1613.2 mg per $100 \mathrm{~g}$ dry weight) in quinoa seeds (Pulvento et al., 2012). Gas chromatography (GC) applied for the evaluation of saponin aglycones showed three major quinoa saponin aglycones: oleanolic acid (36-50\% of the total), hederagenin (27-28\%), and phytolaccagenic acid (21-36\%). HPLC-DAD-ESI-MS analysis of phenolic compounds indicated that irrigation to achieve $25 \%$ of full water restitution caused an increase in free phenolics of $23.16 \%$ (with salt) and $26.27 \%$ (without), while the bound phenolic compounds were not influenced by environmental stress (Gómez-Caravaca et al., 2012).

In addition, Riccardi et al. (2014) highlighted that the treatment representing a reduction in the irrigation water to $25 \%$ of that in the control treatment $(\mathrm{Q} 25)$ caused an increase in water productivity (WP) of 1.12 and $0.95 \mathrm{~kg} \mathrm{~m}^{-3}$ in 2009 and 2010, respectively, and reduced dry matter accumulation in the leaves. Q25 plants were initially negatively affected by severe drought, with a reduction in the relative growth rate (RGR) and net assimilation ratio (NAR), but they then adapted to it. The results indicated that quinoa could be considered to be a drought-tolerant crop that alters its photosynthetic rate to compensate for reduced growth (Riccardi et al., 2014).

Cocozza et al. (2013) observed that as water and salt stress developed and the leaf water potential $\left(\Psi_{\text {leaf }}\right)$ decreased, the leaf osmotic potential $\left(\Psi_{p}\right)$ declined (below -2.05 MPa) to maintain turgor. Stomatal conductance $\left(\mathrm{g}_{\mathrm{s}}\right)$ decreased with the reduction in $\Psi 1_{\text {eaf }}$ (with a steep drop at $\Psi_{\text {leaf }}$ between -0.8 and $1.2 \mathrm{MPa}$ ) and $\Psi_{\mathrm{p}}$ (with a steep drop at $\Psi_{\mathrm{p}}$ between -1.2 and -1.4 MPa). Salt and drought stress did not influence the relationship between the water potential components, relative water content (RWC) and $g_{s}$. The effects of salinity and drought resulted in strict dependencies between RWC and water potential components, showing that regulating cellular water deficit and volume is a powerful mechanism for conserving cellular hydration under stress, resulting in osmotic adjustment in association with turgor loss. In conclusion, quinoa presents good resistance to water and salt stress through stomatal responses and osmotic adjustments that contribute to the maintenance of leaf turgor propitious to plant growth and preserved crop yield in Mediterranean cropping systems.

\section{Experiments and Results in Turkey}

Quinoa was cultivated for the first time in Turkey in 2008 within the framework of the European Union project entitled "Sustainable water use securing food production in dry areas of the Mediterranean region" (SWUP-MED). The scope of the research program was to improve crop production in the Mediterranean region under multiple abiotic stresses becoming more distinct under climate change (Yazar, 2015; Yazar et al., 2015).

Field experiments were performed in the experimental field of the Irrigation and Agricultural Structures Department of Cukurova University in Adana, Turkey $\left(36^{\circ} 59^{\prime} \mathrm{N}, 35^{\circ} 18^{\prime} \mathrm{E}, 50 \mathrm{~m}\right.$ above sea level) from 2009 to 2011 to evaluate the response of quinoa (Chenopodium quinoa Willd. 
cv. 'Titicaca') to saline and fresh water under Mediterranean climatic conditions (Yazar and Incekaya, 2014; Yazar, 2015).

The first experiment in 2009 included a total of four different irrigation treatments: full irrigation using fresh water (FIF); full irrigation using saline water (FIS); deficit irrigation (DI); and partial root-zone drying (PRD). The plants in the DI and PRD treatments were irrigated with fresh water. Under PRD, half of the root zone was wetted, while the other half was kept partially dry. Quinoa seeds were sown by hand (3-4 $\mathrm{cm}$ apart with 50-cm row spacing) on 10 April 2009. The quinoa received a total of $302 \mathrm{~mm}$ of water under the FIF treatment and a total of $151 \mathrm{~mm}$ of water under the DI and PRD treatments. According to the results of this experiment, no significant differences were observed in grain yield [values ranged from $1691 \mathrm{~kg} \mathrm{ha}^{-1}$ (DIF) to $2120 \mathrm{~kg} \mathrm{ha}^{-1}$ (FIF)] or dry matter yield [values ranged from $1649.2 \mathrm{~g} \mathrm{~m}^{-2}$ (PRD) to $1932.5 \mathrm{~g} \mathrm{~m}^{-2}$ (FIF)] between the different irrigation treatments. The highest leaf area index (LAI: 4.5) was found in the FIF plots, while the highest water productivity (WP: $0.58 \mathrm{~kg} \mathrm{~m}^{3}$ ) and irrigation water use efficiency (IWUE: $0.93 \mathrm{~kg} \mathrm{~m}^{3}$ ) were recorded under the PRD treatment (Yazar, 2015).

The 2010 and 2011 experiments compared different irrigation treatments: full irrigation using fresh water (FIF), full irrigation using saline water with different salt concentrations (FIS 40 $\mathrm{dS} \mathrm{m}^{-1}$, FIS $30 \mathrm{dS} \mathrm{m}^{-1}$, FIS $20 \mathrm{dS} \mathrm{m}^{-1}$, FIS $10 \mathrm{dS}$ $\mathrm{m}^{-1}$ ), deficit irrigation with fresh water (DIF 50 and DIF 75 of full irrigation), partial root-zone drying (PRD), and deficit irrigation with saline water of $40 \mathrm{dS} \mathrm{m}^{-1}$ (DIS $50 \%$ of full irrigation). In 2012, in addition to the full irrigation treatments, two deficit irrigation levels of $67 \%$ and $33 \%$ of full irrigation with fresh or saline (30, 20, $10 \mathrm{dS} \mathrm{m}^{-1}$ ) water were studied. (Yazar et al., 2015). The results indicated that grain yields were slightly reduced by irrigation water salinity up to $30 \mathrm{dS} \mathrm{m}^{-1}$ in comparison to fresh water irrigation. In 2010, the grain yield varied from $1714 \mathrm{~kg} \mathrm{ha}^{-1}$ in the nonirrigated treatment to $3169 \mathrm{~kg} \mathrm{ha}^{-1}$ in the FIS $40 \mathrm{dS} \mathrm{m}^{-1}$ treatment. In 2011, grain yield per plant ranged between $23.19 \mathrm{~g}$ in the nonirrigated treatment and $31.80 \mathrm{~g}$ in the FIF treatment. Grain yields in 2012 were considerably lower than those in the other years, as quinoa seedlings were used instead of direct sowing. The highest grain yield was obtained for FIF (1960 kg ha-1), followed by FIS $10 \mathrm{dS} \mathrm{m}^{-1}\left(1920 \mathrm{~kg} \mathrm{ha}^{-1}\right)$, FIS $30 \mathrm{dS} \mathrm{m}^{-1}$ (1910 $\left.\mathrm{kg} \mathrm{ha}^{-1}\right)$ and FIS $20 \mathrm{dS} \mathrm{m}^{-1}\left(1870 \mathrm{~kg} \mathrm{ha}^{-1}\right)$. The grain yield decreased as the amount of irrigation water decreased. In terms of biomass yield, the highest yields in 2010 were found in the FIF $(6786 \mathrm{~kg}$ $\left.\mathrm{ha}^{-1}\right)$ and FIS $40 \mathrm{dS} \mathrm{m}^{-1}\left(6889 \mathrm{~kg} \mathrm{ha}^{-1}\right)$ treatment plots, whereas the nonirrigated $\left(1714 \mathrm{~kg} \mathrm{ha}^{-1}\right)$ and DIS 50\% (1889 $\left.\mathrm{kg} \mathrm{ha}^{-1}\right)$ plants showed the lowest yields. Although irrigation water salinity of $40 \mathrm{dS}$ $\mathrm{m}^{-1}$ did not considerably influence biomass yield, the water and salinity stress that occurred together in the DIS 50\% treatment reduced biomass yields significantly. In 2012, the highest biomass yield was found in the FIF treatment $\left(6121 \mathrm{~kg} \mathrm{ha}^{-1}\right)$, followed by FIS $30 \mathrm{dS} \mathrm{m}^{-1}\left(6084 \mathrm{~kg} \mathrm{ha}^{-1}\right)$, while the lowest biomass yields were recorded in the saline water with deficit irrigation treatments (DIS $10 \mathrm{dS} \mathrm{m}^{-1} 33 \%$ : $4442 \mathrm{~kg} \mathrm{ha}^{-1}$, DIS $20 \mathrm{dS} \mathrm{m}^{-1} 33 \%$ : $4258 \mathrm{~kg} \mathrm{ha}^{-1}$, DIS $30 \mathrm{dS} \mathrm{m}{ }^{-1} 33 \%$ : $4453 \mathrm{~kg} \mathrm{ha}^{-1}$ ) and non-irrigated plots (4443 $\left.\mathrm{kg} \mathrm{ha}^{-1}\right)$. Finally, according to this study, the yield parameters, such as aboveground biomass and seed yield, suggest good adaptation of quinoa cultivar 'Titicaca' to Mediterranean environments (Yazar et al., 2015).

In 2014 and 2015, the effect of drainage water applied with a line-source sprinkler system at different growth stages on yield, yield components, vegetative growth, water use efficiency and salt accumulation in the plant root zone of quinoa was investigated (Sezen et al., 2016). The two-year experiment was conducted in the experimental field of the Irrigation and Agricultural Structures Department of the Cukurova University in Adana, Turkey. Five irrigation levels [one representing full irrigation (I1) and four representing deficit (I2-I5)] were considered. The I2, I3, I4 and I5 treatments represented irrigation deficits of ap- 
proximately $80,60,40$, and $20 \%$, respectively. The total amount of drainage water applied to treatment I1 was 344 and $400 \mathrm{~mm}$ for the two experimental years, respectively, and the total amount of seasonal water use (ET) was 514 and $459 \mathrm{~mm}$. The highest seed yield (4510 and $4880 \mathrm{~kg}$ $\mathrm{ha}^{-1}$ in 2015 and 2014, respectively) and thousandseed weight (3.5 and $3.6 \mathrm{~g}$ in 2015 and 2014, respectively) were observed in the I1 treatment. In addition, the results revealed that there were no significant differences in water use efficiency (WUE) among the irrigation treatments ( 0.95 to $1.03 \mathrm{~kg} \mathrm{~m}^{-3}$ in 2014 and $0.94-1.10 \mathrm{~kg} \mathrm{~m}^{-3}$ in 2015). The soil salinity at the beginning of the growing season varied from 0.63 to $0.72 \mathrm{dS} \mathrm{m}^{-1}$, and the application of drainage water resulted in an increase up to $1.69 \mathrm{dS} \mathrm{m}^{-1}$. Soil salinity decreased with increasing depth in all treatments. Sezen et al. (2016) concluded that full irrigation using drainage water is recommended for sprinklerirrigated quinoa to obtain higher yield and better quality under Mediterranean conditions.

A 2-year experiment was carried out during 2013 and 2014 at the Bornova experimental fields of the Agricultural Faculty of Ege University in Izmir, Turkey $\left(38^{\circ} 27^{\prime} \mathrm{N}, 27^{\circ} 13^{\prime} \mathrm{E}, 20 \mathrm{~m}\right.$ above sea level). The study aimed to evaluate the effects of seven nitrogen application rates $(0,50,75$, $100,125,150$ and $175 \mathrm{~kg} \mathrm{ha}^{-1}$ ) on seed yield and yield components of the quinoa cultivar ' $Q-52$ ' (Geren, 2015). The results showed that it is possible to produce an average quinoa seed yield of $2.95 \mathrm{t} \mathrm{ha}^{-1}$ with an average of $16 \%$ crude protein content under the $150 \mathrm{~kg} \mathrm{~N}^{-1}$ treatment under Mediterranean climate conditions (Geren, 2015).

\section{Conclusions}

Quinoa is commonly accepted to be a stresstolerant plant that is well adapted to different environmental conditions due to its wide genetic variability. In addition to these features, the exceptional nutritional quality of quinoa suggests that this plant is an important crop for food security and animal nutrition. In recent years, quinoa has gained increasing interest on a global scale, and it has been introduced to many countries in Europe, North America, Africa, and Asia for cultivation. The research results in Greece, Italy, and Turkey indicate that quinoa is well adapted to the Mediterranean region. In conclusion, quinoa may be suggested to be a new alternative crop for semiarid and arid Mediterranean conditions affected by multiple abiotic stress factors because of its stresstolerant characteristics, adaptability to several agro-ecological conditions, and nutritional and economic value.

\section{Resumen}

D.J. Bilalis, I. Roussis, I. Kakabouki, y A. Folina. 2019. Cultivo de quinua (Chenopodium quinoa Willd.) en condiciones mediterráneas: una revisión. Cien. Inv. Agr. 46(2): 51-68. La quinua es un cultivo pseudocereal bien adaptado a una amplia gama de condiciones climáticas, y tiene un potencial significativo para aumentar la producción como un nuevo cultivo en la región del Mediterráneo y en otras partes del mundo, incluyendo Europa del Norte, América del Norte, Asia y África. Debido a sus excepcionales propiedades nutricionales, la quinua es muy apreciada tanto en la nutrición humana como en la animal para la alimentación tanto de rumiantes como de animales no rumiantes. Los datos obtenidos de varios estudios realizados en Grecia, Italia y Turquía demuestran el alto potencial nutricional y funcional de la quinua. La fertilización con nitrógeno presenta un efecto positivo sobre el crecimiento y el rendimiento de grano del cultivo de quinua. La biomasa tiene una alta proteína cruda y baja en fibra, y es competitiva con la alfalfa. La evaluación del contenido de saponina de la quinua tiene una gran importancia para la industria. El mayor contenido y rendimiento de saponina se ha encontrado 
en los sistemas de cultivo orgánico. Las plantas de avena, frijol y lenteja de agua tienen una gran respuesta fitotóxica, especialmente de los tejidos de inflorescencia de la quinua, lo que confirma la actividad alelopática potencial de este cultivo prometedor. Como conclusión, se puede sugerir la quinua como un nuevo cultivo alternativo para las condiciones mediterráneas semiáridas y áridas, afectadas por múltiples factores de estrés abióticos debido a sus características de tolerancia al estrés, la adaptabilidad a varias condiciones agroecológicas, así como su valor nutricional y económico.

Palabras clave: Alelopatía, cuenca mediterránea, cultivos forrajeros, saponinas, sistema radicular.

\section{References}

Adams, R.M., B.H. Hurd, S. Lenhart, and N. Leary. 1998. Effects of global climate change on agriculture: an interpretative review. Climate Research. 11:19-30.

Adolf, V.I., S.E. Jacobsen, and S. Shabala. 2013. Salt tolerance mechanisms in quinoa (Chenopodium quinoa Willd.). Environmental and Experimental Botany. 92:43-54.

Ahamed, N.T., R.S. Singhal, P.R. Kulkarni, and M. Pal. 1996. Physicochemical and functional properties of Chenopodium quinoa starch. Carbohydrate Polymers. 31:99-103.

Bazile, D., and F. Baudron. 2015. The dynamics of the global expansion of quinoa growing in view of its high biodiversity. In: Bazile, D., D. Bertero, and C. Nieto (Eds.), State of the Art Report of Quinoa in the World in 2013. FAO \& CIRAD, Rome, pp. 42-55.

Bazile, D., C. Pulvento, A. Verniau, M.S. Al-Nusairi, D. Ba, J. Breidy, L. Hassan, M.I. Mohammed, O. Mambetov, M. Otambekova, N.A. Sepahvand, A. Shams, D. Souici, K. Miri, and S. Padulosi. 2016. Worldwide Evaluations of Quinoa: Preliminary Results from Post International Year of Quinoa FAO Projects in Nine Countries. Frontiers in Plant Science. 7:850.

Bhargava, A., S. Shukla, and D. Ohri. 2006. Chenopodium quinoa-An Indian perspective. Industrial Crops and Products. 23:73-87.

Bilalis, D., I. Kakabouki, A. Karkanis, I. Travlos, V. Triantafyllidis, and D. Hela. 2012. Seed and saponin production of organic quinoa (Chenopodium quinoa Willd.) for different tillage and fer- tilization. Notulae Botanicae Horti Agrobotanici Cluj-Napoca. 40(1):42-46.

Bilalis, D., I. Roussis, F. Fuentes, I. Kakabouki, and I. Travlos. 2017. Organic agriculture and innovative crops under Mediterranean conditions. Notulae Botanicae Horti Agrobotanici Cluj-Napoca. 45:323-331.

Bilalis, D.J., I.S. Travlos, A. Karkanis, M. Gournaki, G. Katsenios, D. Hela, and I. Kakabouki. 2013. Evaluation of the allelopathic potential of quinoa (Chenopodium quinoa Willd.). Romanian Agricultural Research. 30:359-364.

Blanco, J.A. 2015. Fodder and animal feed. In: Bazile, D., D. Bertero, and C. Nieto (Eds.), State of the Art Report of Quinoa in the World in 2013. FAO \& CIRAD, Rome, p. 250-266.

Carlson, D., J.A. Fernandez, H.D. Poulsen, B. Nielsen, and S.E. Jacobsen. 2012. Effects of quinoa hull meal on piglet performance and intestinal epithelial physiology. Journal of Animal Physiology and Animal Nutrition. 96(2):198205.

Ceccarelli, S., S. Grando, and M. Baum. 2007. Participatory Plant Breeding in Water-Limited Environments. Experimental Agriculture. 43(4):411435.

Choukr-Allah, R., N.K. Rao, A. Hirich, M. Shahid, A. Alshankiti, K. Toderich, S. Gill, and K.U.R. Butt. 2016. Quinoa for Marginal Environments: Toward Future Food and Nutritional Security in MENA and Central Asia Regions. Frontiers in Plant Science. 7:346.

Cocozza, C., C. Pulvento, A. Lavini, M. Riccardi, R. d'Andria, and R. Tognetti. 2013. Effects of Increasing Salinity Stress and Decreasing Water 
Availability on Ecophysiological Traits of Quinoa (Chenopodium quinoa Willd.) Grown in a Mediterranean-Type Agroecosystem. Journal of Agronomy and Crop Science. 199:229-240.

Cusack, D. 1984. Quinoa: grain of the Incas. Ecologist 14:21-31.

Eisa, S., M.A. Eid, E.H. Abd El-Samad, S.A. Hussin, A.A. Abdel-Ati, N.E. El-Bordeny, S.H. Ali, M.A. Al-Sayed, Hanan, M.E. Lotfy, A.M. Masoud, A.M. El-Naggar and M. Ebrahim. 2017. Chenopodium quinoa Willd. A new cash crop halophyte for saline regions of Egypt. Australian Journal of Crop Science. 11:343-351.

Food and Agriculture Organization of the United Nations (FAO) (2012). Food and Agriculture Organization of the United Nations - Statistics. Retrieved 2019 February 7 from http://faostat. fao.org.

Fleming, J.E., and N.W. Galwey. 1995. Quinoa (Chenopodium quinoa). In: Williams, J.T. (Ed.), Cereals and Pseudocereals. Chapman and Hall, London.

Francis, G., Z. Kerem, H.P.S. Makkar, K., Becker. 2002. The biological action of saponins in animal systems: A review. British Journal of Nutrition 88(6):587-605.

Fuentes, F., and A. Bhargava. 2011. Morphological analysis of quinoa germplasm grown under lowland desert conditions. Journal of Agronomy and Crop Science 197:124-134.

Fuentes, F., D. Bazile, A. Bhargava, and E.A. Martínez. 2012. Implications of farmers' seed exchanges for on-farm conservation of quinoa, as revealed by its genetic diversity in Chile. Journal of Agricultural Science. 150:702-716.

Galwey, N.W. 1992. The potential of quinoa as a multi-purpose crop for agricultural diversification: A review. Industrial Crops and Products 1:101-106.

Galwey, N.W., C.L.A. Leakey, K.R. Price, and G.R. Fenwick. 1990. Chemical composition and nutritional characteristics of quinoa (Chenopodium quinoa Willd.). Food Sciences and Nutrition 42F:241-261.

Garcia, M., D. Raes, and S.E. Jacobsen. 2003. Evapotranspiration analysis and irrigation requirements of quinoa (Chenopodium quinoa) in the Bolivian highlands. Agricultural Water Management. 60:119-134.

Garcia, M., D. Raes, S.E. Jacobsen, and T. Michel. 2007. Agroclimatic contraints for 6 rainfed agriculture in the Bolivian Altiplano. Journal of Arid Environments 71:109-121.

Geren, H. 2015. Effects of Different Nitrogen Levels on the Grain Yield and Some Yield Components of Quinoa (Chenopodium quinoa Willd.) under Mediterranean Climatic Conditions. Turkish Journal of Field Crops. 20(1):59-64.

Gómez-Caravaca, A.M., G. Iafelice, A. Lavini, C. Pulvento, M.F. Caboni, and E. Marconi. 2012. Phenolic Compounds and Saponins in Quinoa Samples (Chenopodium quinoa Willd.) Grown under Different Saline and Nonsaline Irrigation Regimens. Journal of Agricultural and Food Chemistry. 60:4620-4627.

Gregory, P.J. 2006. Food Production under Poor, Adverse Climatic Conditions. Proceedings IX ESA Congress, 4-7 September 2006, Warsaw, Poland, pp.19.

Güçlü-Üstündag, Ö, and G. Mazza. 2007. Saponins: Properties, Applications and Processing. Critical Reviews in Food Science and Nutrition. 47(3):231-258.

Hariadi, Y., K. Marandon, Y. Tian, S.E. Jacobsen, and S. Shabala. 2011. Ionic and osmotic relations in quinoa (Chenopodium quinoa Willd.) plants grown at various salinity levels. Journal of Experimental Botany. 62:185-193.

Hasanuzzaman, M., K. Nahar, Md. M. Alam, P.C. Bhowmik, Md. A. Hossain, M.M. Rahman, M.N.V. Prasad, M. Ozturk, and M. Fujita. 2014. Potential Use of Halophytes to Remediate Saline Soils. BioMed Research International. Volume 2014, Article ID 589341, 12 pages.

Hasegawa, P.M. 2013. Sodium $\left(\mathrm{Na}^{+}\right)$homeostasis and salt tolerance of plants. Environmental and Experimental Botany. 92:19-31.

Hinojosa, L., J.A. González, F.H. Barrios-Masias, F. Fuentes, K.M. Murphy. 2018. Quinoa Abiotic Stress Responses: A Review. Plants. 7:106.

Hirose, Y., T. Fujita, T. Ishiic, and N. Ueno. 2010. Antioxidative properties and flavonoid composi- 
tion of Chenopodium quinoa seeds cultivated in Japan. Food Chemistry. 119(4):1300-1306.

Iliades, C., T. Karyotis, and S.E. Jacobsen. 1999. Effect of sowing date on seed quality and yield of Quinoa (Chenopodium quinoa) in Greece. In: Crop development for the cool and wet regions of Europe: Workshop on alternative crops for sustainable agriculture of the COST Action 814, BioCity, Turku, Finland, pp. 226-231.

Iliadis, C., T. Karyotis, and S. E. Jacobsen. 2001. Adaptation of quinoa under xerothermic condtions and cultivation for biomass and fibre production. In: Jacobsen, S.E., A. Mujica, and Z. Portillo (Eds.) Memorias, Primer Taller Internacional sobre Quinua - Recursos Geneticos y Sistemas de Producción, UNALM, International Potato Center (CIP), Lima, Peru, pp. 371-378.

Iliadis, C., T. Karyotis, and T. Mitsibonas. 1997. Research on Quinoa (Chenopodium quinoa Willd.) and Amaranth (Amarantus caudatus) in Greece, in crop development for the cool and wet regions of Europe. In: Ortiz, R., and O. Stølen (Eds.), Workshop on small grain cereals and pseudocereals of the COST Action 814, Wageningen, The Netherlands, pp. 85-91.

Jacobsen, E.E., B. Skadhauge, S.-E. Jacobsen. 1997. Effect of dietary inclusion of quinoa on broiler growth performance. Animal Feed Science and Technology. 65:5-14.

Jacobsen, S.E. 2003. The worldwide potential for quinoa (Chenopodium quinoa Willd.). Food Reviews International. 19(1-2):167-177.

Jacobsen, S.E. 2014. New Climate-Proof Cropping Systems in Dry Areas of the Mediterranean Region. Journal of Agronomy and Crop Science. 200:399-401.

Jacobsen, S.E. 2017. The scope for adaptation of quinoa in northern latitudes of Europe. Journal of Agronomy and Crop Science. 203:603-613.

Jacobsen, S.E., and A. Mujica. 2003. Quinoa: An alternative crop for saline soils. Journal of Experimental Botany. 54:25.

Jacobsen, S.E., and O. Stolen. 1993. Quinoa-morphology, phenology and prospects for its production as a new crop in Europe. European Journal of Agronomy. 2(1):19-29.
Jacobsen, S.E., A. Mujica, and C.R. Jensen. 2003. Resistance of quinoa (Chenopodium quinoa Willd.) to adverse abiotic factors. Food Reviews International. 19(1-2):99-109.

Jamil, A., S. Riaz, M. Ashraf, and M.R. Foolad. 2011. Gene Expression Profiling of Plants under Salt Stress. Critical Reviews in Plant Science. 30(5):435-438.

Jensen, C.R., S.E. Jacobsen, M.N. Andersen, N. Núńez, S.D. Andersen, L. Rasmussen, and Mogensen. 2000. Leaf gas exchange and water relation characteristics of field quinoa (Chenopodium quinoa Willd.) during soil drying. European Journal of Agronomy. 13:11-25.

Joffre, R., and S. Rambal. 2001. Mediterranean Ecosystems. Chichester, eLS. John Wiley \& Sons Ltd. Retrieved February 3, 2019 from https://www.e-proof. sps.co.in/ ja.asp?rfp=pipffivini.

Kakabouki, I. 2016. Remediation possibility of nitrate-contaminated soils using Quinoa crop. $\mathrm{PhD}$ Thesis. University of Patras, Greece, p. 178.

Kakabouki, I., D. Bilalis, A. Karkanis, G. Zervas, E. Tsiplakou, and D. Hela. 2014. Effects of fertilization and tillage system on growth and crude protein content of quinoa (Chenopodium quinoa Willd.): An alternative forage. Emirates Journal of Food and Agriculture. 26:18-24.

Kakabouki, I., A. Karkanis, I.S. Travlos, D. Hela, P. Papastylianou, H. Wu, D. Chachalis, R. Sestras, and D. Bilalis. 2015. Weed flora and seed yield in quinoa crop (Chenopodium quinoa Willd.) as affected by tillage systems and fertilization practices. International Journal of Pest Management. 61(3):228-234.

Kakabouki, I.P., D. Hela, I. Roussis, P. Papastylianou, A.F. Sestras, and D.J. Bilalis. 2018. Influence of fertilization and soil tillage on nitrogen uptake and utilization efficiency of quinoa crop (Chenopodium quinoa Willd.). Journal of Soil Science and Plant Nutrition. 18(1): 220-235.

Karyotis, T., C. Iliadis, C. Noulas, and T. Mitsibonas. 2003. Preliminary research on seed production and nutrient content for certain quinoa varieties in a saline-sodic soil. Journal of Agronomy and Crop Science. 189(6):402-408. 
Kökten, K, T. Karaköy, A. Bakoğlu, and M. Akçura. 2010. Determination of salinity tolerance of some lentil (Lens culinaris M.) varieties. Journal of Food, Agriculture and Environment 8(1):140-143.

Koziol, M.J. 1992. Chemical composition and nutritional value of quinoa (Chenopodium quinoa Willd.). Journal of Food Composition and Analysis. 5:35-68.

Kuljanabhagavad, T., P. Thongphasuk, W. Chamulitrat, and M. Wink. 2008. Triterpene saponins from Chenopodium quinoa Willd. Phytochemistry. 69(9):1919-1926.

Lavini, A., C. Pulvento, R. d'Andria, M. Riccardi, R. Choukr-Allah, O. Belhabib, A. Yazar, C. Incekaya, S. Metin Sezen, M. Qadir, and S.E. Jacobsen. 2014. Quinoa's Potential in the Mediterranean Region. Journal of Agronomy and Crop Science. 200:344-360.

Li, G., and F. Zhu. 2018. Quinoa starch: Structure, properties, and applications. Carbohydrate Polymers. 181:851-861.

Lopez-Garcia, R. 2007. Quinoa: A traditional Andean crop with new horizons. Cereal Foods World. 52: 88-90.

Mastebroek, H.D., and H. Limburg. 1996. Breeding for harvest security in Chenopodium quinoa. Proceedings of the COST-Workshop., 22-24/2 1996 European Commission EUR 17473/KVL, Copenhagen, KVL, pp. 79-86.

Mastebroek, H.D., H. Limburg, T. Gilles, and H.J.P. Marvin. 2000. Occurrence of sapogenins in leaves and seeds of Quinoa (Chenopodium quinoa Willd.). Journal of the Science of Food and Agriculture. 80:152-156.

Matsubara K, K. Ishihara, Y. Mizushina, M. Mori, and N. Nakajima. 2004. Anti-angiogenic activity of quercetin and its derivatives. Letters in Drug Design and Discovery. 1: 329-333.

Mujica, A., S.E. Jacobsen, J. Ezquierdo, and J.P. Marathee. 2001. Resultados de la Prueba Americana y Europes de la Quinua. FAO, UNAPuno, CIP, p. 51.

Munns, R., and M. Tester. 2008. Mechanisms of salinity tolerance. Annual Review of Plant Biology. 59:651-681.

Noulas, C., M. Tziouvalekas, D. Vlachostergios, D. Baxevanos, T. Karyotis, and C. Iliadis. 2017.
Adaptation, Agronomic Potential, and Current Perspectives of Quinoa Under Mediterranean Conditions: Case Studies from the Lowlands of Central Greece. Communications in Soil Science and Plant Analysis. 48(22):2612-2629.

Nowak, V., J. Du, and U.R. Charrondière. 2016. Assessment of the nutritional composition of quinoa (Chenopodium quinoa Willd.). Food Chemistry 193:47-54.

Papastylianou, P., I. Kakabouki, E. Tsiplakou, I. Travlos, D. Bilalis, D. Hela, D. Chachalis, G. Anogiatis, and G. Zervas. 2014. Effects of fertilization on yield and quality of biomass of quinoa (Chenopodium quinoa Willd.) and green amaranth (Amaranthus retroflexus L.). Bulletin UASVM Horticulture. 71(2):287-292.

Peterson, A., and K. Murphy. 2015. Quinoa cultivation for temperate North America: Considerations and areas for investigation. In: Murphy, K., and J. Matanguihan (Eds.), Quinoa: Improvement and Sustainable Production. John Wiley \& Sons, Inc., Hoboken, NJ, USA., pp.173-192.

Pulvento, C., M. Riccardi, A. Lavini, R. d'Andria, G. Iafelice, and E. Marconi. 2010. Field trial evaluation of two Chenopodium quinoa genotypes grown under rain-fed conditions in a typical Mediterranean environment in southern Italy. Journal of Agronomy and Crop Science. 196:407-411.

Pulvento, C., M. Riccardi, A. Lavini, G. Iafelice, E. Marconi, and R. d'Andria. 2012. Yield and quality characteristics of quinoa grown in open field under different saline and non-saline irrigation regimes. Journal of Agronomy and Crop Science. 198:254-263.

Ragab, R., and C. Prudhomme, 2002. Climate change and water resources management in arid and semi-arid regions: prospective and challenges for the 21st century. Biosystems Engineering. 81(1):3-34.

Razzaghi, F., S.H. Ahmadi, V.I. Adolf, C.R. Jensen, S.E. Jacobsen, and M.N. Andersen. 2011. Water relations and transpiration of Quinoa (Chenopodium quinoa Willd.) under salinity and soil drying. Journal of Agronomy and Crop Science. 197:348-360. 
Razzaghi, F., S.H. Ahmadi, S.-E. Jacobsen, C.R. Jensen, and M.N. Andersen. 2012. Effects of salinity and soil-drying on radiation use efficiency, water productivity and yield of Quinoa (Chenopodium quinoa Willd.) Journal of Agronomy and Crop Science. 198:173-184.

Repo-Carrasco, R., C. Espinoza, and S.-E. Jacobsen, 2003: Nutritional value and use of the Andean crops quinoa (Chenopodium quinoa) and kañiwa (Chenopodium pallidicaule). Food Reviews International. 19:179-189.

Riccardi, M., C. Pulvento, A. Lavini, R. d'Andria, and S.E. Jacobsen. 2014. Growth and Ionic Content of Quinoa Under Saline Irrigation. Journal of Agronomy and Crop Science. 200:246-260.

Risi, J.C., and N.W. Galwey. 1984. The Chenopodium grains of the Andes: Inca crops for modern agriculture. Advanced Applied Biology. 10:145-216.

Ruales, J., and B.M. Nair. 1993. Content of fat, vitamins and minerals in quinoa (Chenopodium quinoa, Willd) seeds. Food Chemistry. 48(2):131136.

Ruiz, K.B., S. Biondi, E.A. Martınez, F. Orsini, F. Antognoni, S.-E. Jacobsen (2016). Quinoa - A model crop for understanding salt tolerance mechanisms in halophytes. Plant Biosystems. 150:357-371.

Ruiz, K.B., S. Biondi, R. Oses, I.S. Acuña-Rodríguez, F. Antognoni, E.A. Martinez-Mosqueira, A. Coulibaly, A. Canahua-Murillo, M. Pinto, A. Zurita-Silva, D. Bazile, S.E. Jacobsen, and M.A. Molina-Montenegro. 2014. Quinoa biodiversity and sustainability for food security under climate change. A review. Agronomy for Sustainable Development. 34:349-359.

Ruiz-Carrasco, K. B., F. Antognoni, A.K. Coulibaly, S. Lizardi, A. Covarrubias, E.A. Martínez, M.A. Molina-Montenegro, S. Biondi, and A. Zurita-Silva. 2011. Variation in salinity tolerance of four lowland genotypes of quinoa (Chenopodium quinoa Willd.) as assessed by growth, physiological traits, and sodium transporter gene expression. Plant Physiology and Biochemistry. 49:1333-1341.

Ruffino, A.M.C., M. Rosa, M. Hilal, J.A. Gonzalez, and F.E. Prado. 2010. The role of cotyledon metabolism in the establishment of quinoa (Cheno- podium quinoa) seedlings growing under salinity. Plant and Soil. 326:213-224.

Sanchez, A.M., S.E. Jacobsen, J. Izqiedo, and J.P. Marathee. 1998. Field Book of the American and European test of Quinoa. In: Smith, B. (Ed.), FAO, UNA-Puno. Communications Unit International Potato Center (CIP), Lima, Peru, p. 37

Scheben, A., Y. Yuan, and D. Edwards. 2016. Advances in genomics for adapting crops to climate change. Current Plant Biology. 6:2-10.

Schulze, E.D., E. Beck, and K. Müller-Hohenstein. 2005. Plant Ecology. Springer-Verlag, Heidelberg.

Sezen, S.M., A. Yazar, S. Tekin, and M. Yildiz. 2016. Use of drainage water for irrigation of quinoa in a Mediterranean environment. Proceedings of 2nd World Irrigation Forum (WIF2), 6-8 November 2016, Chiang Mai, Thailand, W.3.3.07.

Stikic, R., D. Glamoclija, M. Demin, B. VucelicRadovic, Z. Jovanovic, D. Milojkovic-Opsenica, S.E. Jacobsen, and M. Milovanovic. 2012. Agronomical and nutritional evaluation of quinoa seeds (Chenopodium quinoa Willd.) as an ingredient in bread formulations. Journal of Cereal Science. 55:132-138.

Tapia, M.E. 1979. Historia y Distribucion geographica. Quinua y Kaniwa. Cultivos Andinos. In: Tapia, M.E. (Ed.), Serie Libros y Materiales Educativos, vol. 49. Instituto Interamericano de Cien- cias Agricolas, Bogota, Colombia, pp. 11-15.

Tapia, M., 1982. The Environment, Crops and Agricultural Systems in the Andes and Southern Peru. IICA.

Tapia, M.E. 2015. The long journey of Quinoa: who wrote its history? In: Bazile, D., D. Bertero, and C. Nieto (Eds.), State of the Art Report of Quinoa in the World in 2013. FAO \& CIRAD, Rome, pp. 3-9.

Taviani, P., A. Rubini, L. Menconi, G. Pieroni, and F. Damiani. 2008. Introduzione di nuove colture: La quinoa (Chenopodium quinoa Willd.) Progetto Co.Al.Ta. II. Presentati nell'ambito del Progetto Di.Al.Ta. II. Divulgazione delle colture alternative al tobacco Retrieved February 10, 2019, from http://sito.entecra.it/portale/public/ documenti/coalta2_sintesi_finale.pdf. 
Tekin, S., A. Yazar, and H. Barut. 2017. Comparison of wheat-based rotation systems and monocropping systems under dryland Mediterranean conditions. International Journal of Agricultural and Biological Engineering. 10(5):203-213.

Tian, X., H. Tang, H. Lin, G. Cheng, S. Wang, and X. Zhang. 2013. Saponins: the Potential Chemotherapeutic Agents in Pursuing NewAntiglioblastoma Drugs. Mini-Reviews in Medicinal Chemistry. 13:1709-1724.

Trenberth, K.E. 2011. Changes in precipitation with climate change. Climate Research. 47:123-138.

United Nations (UN). 2017. World population projected to reach 9.8 billion in 2050, and 11.2 billion in 2100. United Nations Department of Economic and Social Affairs. Retrieved February 2, 2019, from https://www.un.org/development/ desa/en/news/population/world-populationprospects-2017.html.

Vega-Gálvez, A., M. Miranda, J. Vergara, E. Uribe, L. Puente and E.A. Martínez. 2010. Nutrition facts and functional potential of quinoa (Chenopodium quinoa Willd.), an ancient Andean grain: a review. Journal of the Science of Food and Agriculture. 90:2541-2547.

Wang, W.X., B. Vinocur, and A. Altman, 2003. Plant responses to drought, salinity and extreme temperatures: towards genetic engineering for stress tolerance. Planta. 218:1-14.

White, P.L., E. Alvistur, C. Dias, E. Vinas, H.S. White, and C. Collazos. 1955. Nutrient content and protein quality of quinoa and canihua, edible seed products of the Andes mountains. Journal of Agricultural and Food Chemistry. 3:531-534.

Wright, K.H., K.C. Huber, D.J. Fairbanks, and C.S. Huber. 2002. Isolation and characterization of Atriplex hortensis and sweet Chenopodium quinoa starches. Cereal Chemistry. 79(5):715-719.

Yazar, A. 2015. Quinoa experimentation and production in Turkey. In: Bazile, D., D. Bertero, and C. Nieto (Eds.), State of the Art Report of Quinoa in the World in 2013. FAO \& CIRAD, Rome, p. 466-477.

Yazar, A., and C. Incekaya. 2014. A New Crop for Salt Affected and Dry Agricultural Areas of Turkey: Quinoa (Chenopodium quinoa Willd.). Turkish Journal of Agricultural and Natural Sciences. Special Issue 2:1440-1446.

Yazar, A., C. Incekaya, S.M. Sezen, and S.-E. Jacobsen. 2015. Saline water irrigation of quinoa (Chenopodium quinoa) under Mediterranean conditions. Crop and Pasture Science. 66:9931002.

Zurita-Silva, A., S.-E. Jacobsen, F. Razzaghi, R. Alvarez-Flores, K. B. Ruiz, A. Morales, and H. Silva, 2014: Capitulo 2.4. Respuestas a la sequia y adaptacion de la quinua. In: D. Bazile, D. Bertero, and C. Nieto eds. "Estado del Arte de la Quinua en el Mundo en 2013": Libro de Resumenes, pp. 185-202. FAO/CIRAD, Santiago de Chile/Montpellier. 